\title{
Performance Evaluation of Trickling Filter-Based Wastewater Treatment System Utilizing Cotton Sticks as Filter Media
}

\author{
Mian M. Ahson Aslam ${ }^{1}$, Zahid M. Khan ${ }^{1}$, Muhammad Sultan ${ }^{1 *}$, Yasir Niaz ${ }^{2}$, \\ Muhammad H. Mahmood ${ }^{3}$, Muhammad Shoaib', \\ Aamir Shakoor ${ }^{1}$, Maqbool Ahmad ${ }^{4}$ \\ ${ }^{1}$ Department of Agricultural Engineering, Bahauddin Zakariya University, \\ Bosan Road, Multan 60800, Pakistan \\ ${ }^{2}$ Key Laboratory of Industrial Ecology and Environmental Engineering, Dalian University of Technology, \\ Dalian 116024, China \\ ${ }^{3}$ International Institute for Carbon-Neutral Energy Research (WPI-IㄷNER), Kyushu University, \\ 744 Motooka, Nishi-ku, Fukuoka 819-0395, Japan \\ ${ }^{4}$ Mango Research Institute, Old Shujabad Road, Multan 60000, Pakistan
}

Received: 10 January 2017

Accepted: 12 March 2017

\begin{abstract}
The need of wastewater (WW) treatment is increasing along with the production of WW and its disposal without treatment. With a smaller footprint, ease of operation, and relatively less cost, trickling filter (TF) wastewater treatment systems have been considered to be more adoptable for domestic and industrial WW treatment in underdeveloped and/or developing countries - particularly for Asia and Africa. A relatively lowcost and operationally effective TF wastewater treatment system was developed using farm waste cotton sticks as biofilm support media. During the operation of the TF system, flow rates vary from 1.7 to $4.6 \mathrm{~m}^{3} / \mathrm{hr}$. The attained removal efficiency for BOD (biological oxygen demand) was $69-78 \%$ and for chemical oxygen demand (COD) was $65-80 \%$. The solids removal in TF system was $38-56 \%$ for total suspended solids (TSS) and $20-36 \%$ for total dissolved solids (TDS). Other aggregates such as turbidity and color removal were $32-54 \%$ and $25-42 \%$, respectively. Four to five months of trouble-free operation of the developed TF system indicated the robustness and reliability of the system. Cotton sticks appeared to be a degradation-resistant alternative filter media for the TF system. Moreover, it is useful for reducing potential impacts of WW re-use at the farm level. Treated effluents through the TF system can be re-used as an irrigation water supplement in under-developed and/or developing countries.
\end{abstract}

Keywords: wastewater treatment, trickling filter, cotton sticks, performance evaluation

*e-mail: muhammadsultan@bzu.edu.pk 


\section{Introduction}

The resources of fresh water and population are distributed in an irregular manner on planet Earth. Water supplies are less than the water demand for about $40 \%$ of popularly placed areas around the world. The regions under water scarcity are facing many bad impacts on their development and ground lifestyle due to limited or no access to freshwater. About $60 \%$ of the world's population may potentially face water scarcity in the next 10 to 20 years. The countries in Asia and Africa are rapidly losing their surface water resources [1-7].

The global projected amount of wastewater (WW) production was $450 \times 10^{9} \mathrm{~m}^{3}$ per year in 2010 [8]. Total production of wastewater in a country like Pakistan is $4,369 \times 10^{6} \mathrm{~m}^{3}$ per year, which includes $3,060 \times 10^{6} \mathrm{~m}^{3}$ $(70 \%)$ per year from municipal and $1,309 \times 10^{6} \mathrm{~m}^{3}(30 \%)$ per year from industrial use [9-10]. WW generation through industrial sub-sectors is more than $80 \%$ of total industrial WW. Total estimated amount of WW applying directly to agriculture is $876 \times 10^{6} \mathrm{~m}^{3}(27 \%)$ per year [11]. As per estimation, directly irrigating an area with WW is about 32,500 ha [12]. About 2,000 million gallons of WW is being discharged into natural drains every day [9].

Due to urbanization, the graph of environmental problems such as water supply, WW generation, collection, its treatment, and disposal in urban areas have been raised. The untreated WW usually contains organic contaminants such as pesticides, oil, and some inorganic pollutants like metals, ions, nitrates, sulphates, phosphate, arsenic cadmium, mercury, lead, etc. [13]. Some microorganisms like fungi, bacteria, and viruses, etc., are often found in sewage water in an appreciable amount, which may cause a threat to community health [14]. A large quantity of sewage and other effluents released from urban areas and use of this WW in agricultural and other purposes depends on its contamination level. A small portion of the generated WW goes to limited treatment before entering into rivers or surface water bodies [15]. Due to this addition of WW, the surface water quality is going to decrease and the pollution is going to increase day by day [9, 16-17]. Untreated WW, which contains sludge and other commercial effluents, may flow toward the rivers and finally find its way to irrigation canals. Moreover, it has a potential to cause bacteriological diseases such as polio, dysentery, hepatitis, typhoid, paratyphoid, and bacterial infections [9, 18-20]. Hence disposal of WW without treatment is a serious environmental concern [21], and to get rid of these harms it is necessary to treat the WW before its disposal [22-23].

WW treatment cost can be reduced by applying those beneficial operations, which can provide its proper reuse options, e.g., for agriculture or irrigation, rangeland, and forest. Biological treatment or trickling filters are a cost-effective method for WW treatment. In this process WW is to pass through suitable media. When it comes to contact with a microbial layer generated on the surface of media where treatment is done with degradation of organic matters by the microorganisms, in fact microbes oxidize pollutants and reduce the organic and inorganic contaminants. The major advantages of using bio filtration are ease of operation and maintenance, flexibility against load variation, low construction cost, simple design, energy savings, it is inexpensive, and it requires only a small area for installation [24].

WW treatment is a costly option for underdeveloped and developing countries. Less than $50 \%$ of the globally generated WW is treated [8-9]. The conditions are more severe in developing countries like Pakistan, India, and Bangladesh. Only $8 \%$ of domestic and industrial WW receives treatment to only the primary level $[9,20,25-$ 26]. Therefore, the present study addresses a TF-based WW treatment system that utilizes agricultural waste (i.e., cotton sticks) as biofilm support medium. As cotton sticks are abundantly available in many developing countries, it will result in low-cost WW treatment. Moreover, the treated water will be available for agricultural applications.

\section{Material and Methods}

In the present study, a trickling filter as secondary WW treatment system was selected for sewage treatment. WW treatment by trickling filter is a purely biological process and can be used for municipal and commercial WW treatment. It is simple in design and requires low cost and a small area for installation. Moreover, it enables low energy requirements and less repair and maintenance [25, 27-28].

\section{Experimental Setup}

Cylindrical shaped reactor body was made up of 22 gauge stainless steel. Its diameter was 30 inches $(76.2 \mathrm{~cm})$ and length from top to end was 60 inches $(152.4 \mathrm{~cm})$. Agricultural bio waste material (cotton sticks) used as filter media in developed TF system for microbial growth. Filter media (cotton sticks) was placed vertically in TF system with 51 inches $(129.5 \mathrm{~cm})$ in height and diameter varies from 0.5 to 1.0 inches. A distributor was installed at the top of reactor to spread WW uniformly over filter media. Flow rates were changed with the help of control valves. A drainage layer with 6 inches depth was constructed at the bottom of reactor for ventilation and to flow WW out from the reactor tank for final sedimentation. Normal ventilation also caused by convection currents due to temperature difference between WW and atmospheric air [25, 29]. A settling tank was also provided for collecting and settling WW. A schematic diagram of a developed TF system using cotton sticks as filter media is shown in Fig. 1.

All experiments were conducted on real WW collected at a disposal station in Bahauddin Zakariya University, Multan. The developed TF system was operated at four different hydraulic loading rates, i.e., 1.7, 2.6, 3.8, and $4.6 \mathrm{~m}^{3} / \mathrm{hr}$. The WW collection tank was provided at a fixed gravity head in order to avoid fluctuations and to provide constant and continuous flow of WW to the 


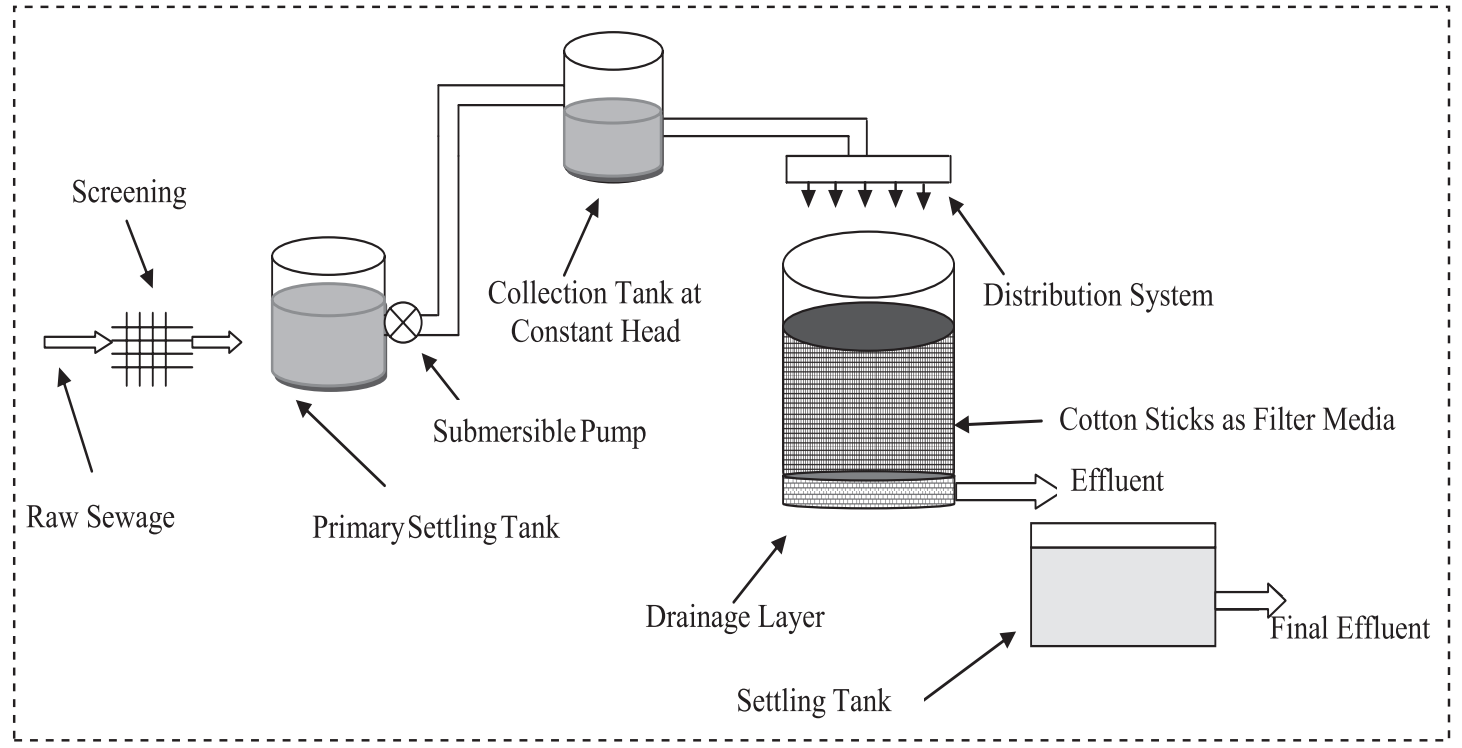

Fig. 1. Schematic diagram of developed trickling filter using cotton sticks as filter media.

system. The performance of developed TF was checked for the above-given hydraulic flow rates by characterizing the influent and effluent samples.

\section{Experimental Procedure}

During the study, all the samples for influent and effluent were taken at regular intervals. $\mathrm{BOD}_{5}$ (once a week) was measured using a five-day BOD test, i.e., 5210B standard method of examination of water and wastewater [30]. COD (five days a week) was measured by standard methods for examination of water and wastewater [30]. TSS, turbidity, and color (five days a week) were measured by using Spectroquant Multi in mg/l. TDS (five days a week) was measured using an Eco Tester TDS low in mg/l [25].
Development of Biofilm

Soon after placing of cotton sticks in reactor tank as filter media, the WW was trickled over the filter media for development of biofilm. Tricking filter was operated for 15 to 30 days for development of biofilm as a startup period [25]. To achieve good quality of treated WW a healthy and active growth of biofilm layer is necessary. The present research was investigated about performance of a developed TF system at different hydraulic flow rates using cotton sticks as filter media. Therefore, for every run of the TF system for a specific hydraulic flow rate the WW distribution over filter media was kept constant for the development of biofilm [25, 31-32]. The potential of cotton sticks in terms of biofilm development is shown in Fig. 2.

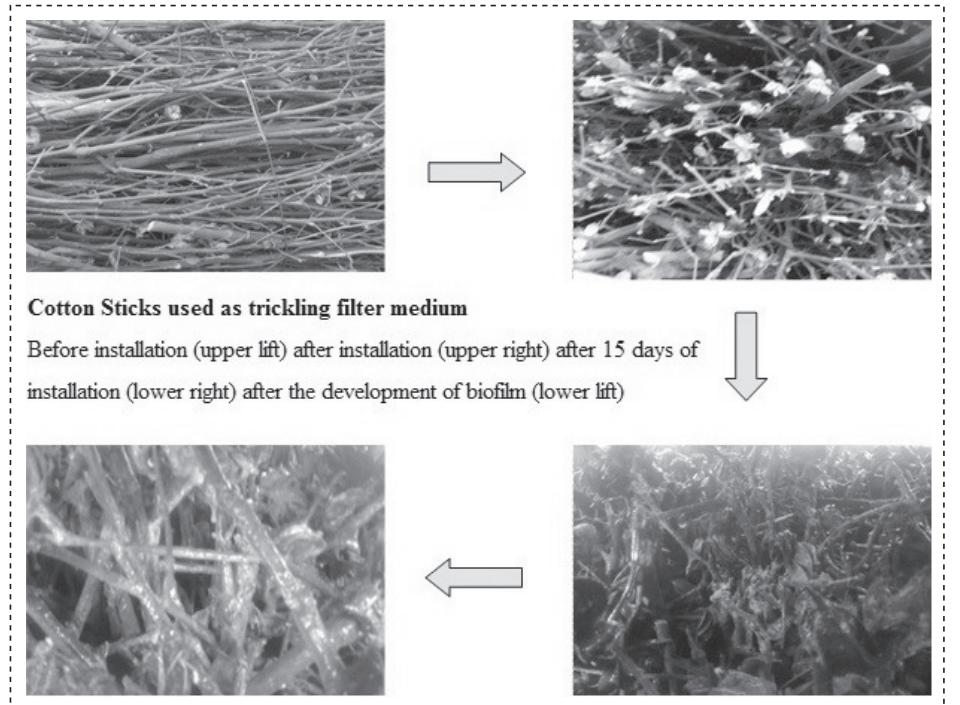

Fig. 2. Before and after the installation of cotton sticks in trickling filter. 
Table 1. Characteristics of raw wastewater before treatment.

\begin{tabular}{|c|c|c|}
\hline Parameters & Range & Average \\
\hline BOD $(\mathrm{mg} / \mathrm{l})$ & $103-278$ & 210.00 \\
\hline $\mathrm{COD}(\mathrm{mg} / \mathrm{l})$ & $139-340$ & 230.00 \\
\hline $\mathrm{pH}(-)$ & $5.31-6.20$ & 5.70 \\
\hline $\mathrm{TSS}(\mathrm{mg} / \mathrm{l})$ & $69-107$ & 95.00 \\
\hline $\mathrm{TDS}(\mathrm{mg} / \mathrm{l})$ & $560-720$ & 658 \\
\hline $\mathrm{DO}(\mathrm{mg} / \mathrm{l})$ & $0.2-1.9$ & 1.12 \\
\hline Turbidity $(\mathrm{FAU})$ & $55-99$ & 84 \\
\hline Color $(\mathrm{Pt} / \mathrm{Co})$ & $450-686$ & 606 \\
\hline Temperature $\left({ }^{\circ} \mathrm{C}\right)$ & $23-45$ & 35.5 \\
\hline
\end{tabular}

\section{Results and Discussion}

The collected WW samples were analyzed for various WW treatment parameters in order to establish the baseline data. Characterization of raw WW is given in Table 1. Average values achieved by the characterization of WW indicate that it is medium strength sewage [27]. It is necessary for biological WW treatment that $\mathrm{BOD}_{5} / \mathrm{COD}$ must be $>0.60$. However, if it is ranging from 0.3 to 0.6 then additional seeding will be required for proper biological treatment because the treatment process will be slow and microbes will take more time for degradation of contaminants. For $\mathrm{BOD}_{5} / \mathrm{COD}<0.30$, biological degradation of WW contaminants will not proceed due to refractive properties and toxicity of the generated WW. Moreover, it prohibits metabolic activity and microbial growth $[25,32]$. In the present study, the influent ratio of $\mathrm{BOD}_{5}$ and COD was more than 0.80 , which indicates that WW doesn't require any pre-treatment or acclimate biomass [33].

\section{BOD and COD}

The influent and effluent BOD concentration ranged from $156-278 \mathrm{mg} / \mathrm{l}$ and $38-80 \mathrm{mg} / \mathrm{l}$, whereas in the case of COD it ranged from 139-342 mg/l and 36-118 mg/l, respectively. It is important to mention that WW quality standards for agricultural reuse are $80 \mathrm{mg} / \mathrm{l}$ for BOD and $150 \mathrm{mg} / \mathrm{l}$ for COD [34]. During the study we observed that BOD and COD removal efficiencies were varied due to ambient air temperature fluctuation during operational days [25]. The TF system showed maximum treatment efficiency of $72-77 \%$ in terms of BOD and $73-79 \%$ in terms of COD at flow rate of $1.7 \mathrm{~m}^{3} / \mathrm{hr}$. The BOD and COD removal efficiencies remained at $62-70 \%$ when the flow rate was 2.6 to $3.8 \mathrm{~m}^{3} / \mathrm{hr}$, as shown in Figs 3-4.

Trickling filter system performance was investigated at four different hydraulic loading rates, namely 1.7, 2.6, 3.8 , and $4.6 \mathrm{~m}^{3} / \mathrm{hr}$, and using these flow rates, system efficiency received $72-77 \%, 71-74 \%, 70-71 \%$, and $69-$ $71 \%$ for BOD, respectively, as shown in Fig. 3. Similarly,

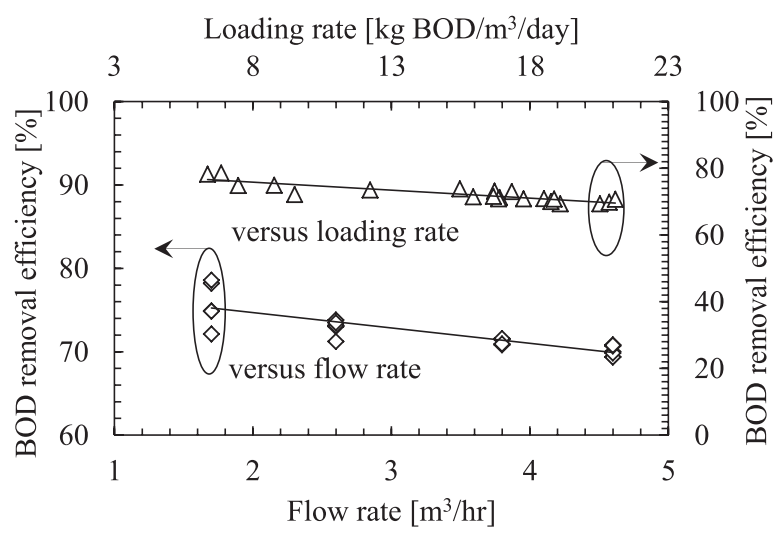

Fig. 3. BOD removal efficiency profile observed for trickling filter system.

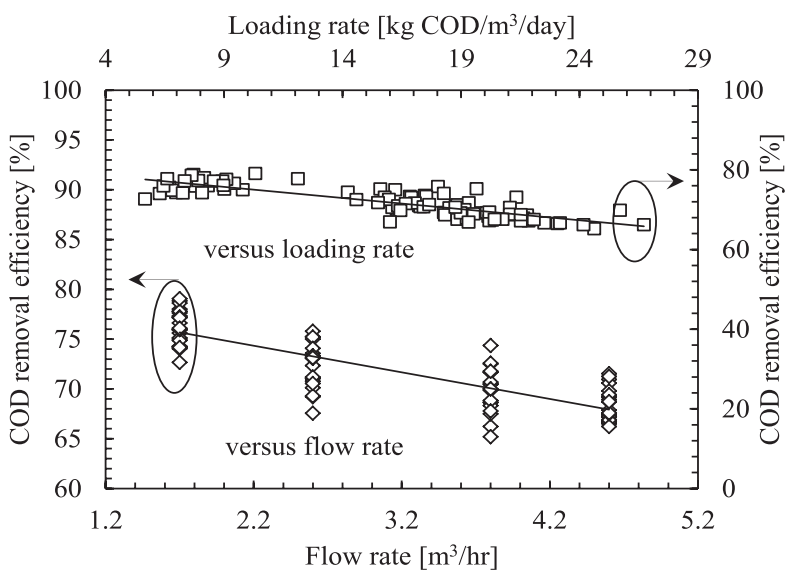

Fig. 4. COD removal efficiency profile observed for trickling filter system.

for COD the TF system efficiency was $73-79 \%, 68-76 \%$, $65-74 \%$, and $66-72 \%$ for flow rates of $1.7,2.6,3.8$, and $4.6 \mathrm{~m}^{3} / \mathrm{hr}$, respectively, as shown in Fig. 4. During the study, overall BOD and COD removal efficiencies ranged from 69 to $77 \%$ and 65 to $79 \%$, respectively. The highest decrease in BOD and COD values was received up to $77 \%$ and $79 \%$, respectively. On the other hand, average BOD and COD removal efficiencies were recorded as 75, 73, 71, and $70 \%$, and $76,72,70$, and $68 \%$ at flow rates of $1.7,2.6$, 3.8 , and $4.6 \mathrm{~m}^{3} / \mathrm{hr}$, respectively. The results showed that as flow rate increased, no significant but a slight decrease in the TF system efficiency was recorded. A study was conducted on trickling filter using pebble gravel as filter media for four different flow rates of 500,600, 700, and $800 \mathrm{~L} / \mathrm{d}$, and the results confirmed that there was no big difference in removal efficiency of COD [29]. A hybrid system was designed for domestic WW treatment and the results from the study showed that as flow rate increased, removal efficiency of the system decreased [35]. The maximum BOD and COD removal efficiencies received during hydraulic flow rate of $1.7 \mathrm{~m}^{3} / \mathrm{hr}$ because of high biological degradation of organic contaminants due to the higher retention time [36]. 
However, the slight decrease in efficiencies of BOD and COD with increasing flow rates $\left(1.7\right.$ to $\left.4.6 \mathrm{~m}^{3} / \mathrm{hr}\right)$ was due to higher hydraulic loading rates that may reduce the residence time of $\mathrm{WW}$ in the TF system, which reduces the contact between liquid and biofilm (Figs 3-4) [36]. It has also been investigated that as flow rate decreases, removal efficiency increases [33, 36-39]. Another study was conducted and results showed that by increasing the hydraulic flow rate the BOD and COD removal efficiencies in the trickling filter remain stable [37].

Higher BOD and COD removal efficiencies were due to higher oxygen availability for maintaining the aerobic zone in the outer portion of the slime layer, which causes the organic substrates to degrade. Low BOD and COD removal efficiencies were due to low oxygen availability, which resulted in increased slime layer thickness and caused anaerobic zone maintenance in the outer portion of this slime layer. The anaerobic zone caused a decrease in the full degradation of organic substrates before being discharged from the trickling filter system [25]. Observed variations in BOD and COD removal efficiencies can also be explained due to the accumulation of biomass with effluent flow and caused a decrease in TF system efficiency [25, 31, 33, 40-43]. High efficiencies of a trickling filter system in terms of BOD and COD removal can be explained by biofilter activity known to be efficient for nitrification [25, 44-45]. In addition, cotton sticks proved to be a sustainable filter media with no notable degradation during the study period. No significant seasonal changes were observed in TF system efficiency due to the long-lasting life of cotton sticks.

During the study period, BOD loading rate varied from 6 to $21 \mathrm{~kg} \mathrm{BOD} / \mathrm{m}^{3} / \mathrm{d}$, and that of COD loading varied from 5 to $26 \mathrm{~kg} \mathrm{COD} / \mathrm{m}^{3} / \mathrm{d}$. It was observed that as the BOD and COD loading rates increased and that BOD and COD removal efficiencies remained within the limits of $70-80 \%$ as shown in Figs 3 and 4 . Most of the studies investigated that with increasing loading rates system efficiency decreases. This occurred due to the varying loadings in the influent can cause an increase in average effluent concentration because of the decrease in retention time of WW to contact with slime layer to oxidize the organic matters as well as the non-uniform development of biofilm in the internal structure [33, 42, 46-49].

\section{TSS and TDS}

Solids residue determination is a very important parameter in WW treatment, which indicates the physical state of principal constituents. TSS and TDS removal performance of the TF system using cotton sticks as biogenic support media was investigated at different flow rates of $2.6,3.8,1.7$, and $4.6 \mathrm{~m}^{3} / \mathrm{hr}$. During the study we observed that TSS removal in WW is related to COD reduction. As TSS was reduced, the COD concentration also decreased in effluent. In untreated WW (influent), the value of TSS ranged from 69 to $107 \mathrm{mg} / \mathrm{l}$, and after the treatment of WW (effluent) the concentration ranged from 39 to $60 \mathrm{mg} / \mathrm{l}$. Average TSS removal efficiency

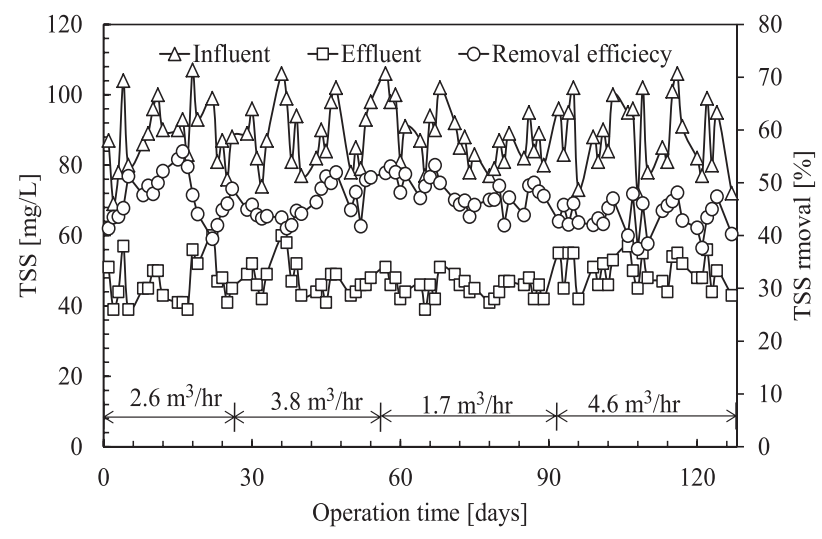

Fig. 5. TSS removal efficiency profile observed for trickling filter system.

was achieved $47,46,48$, and $44 \%$ at flow rates of 2.6 , $3.8,1.7$, and $4.6 \mathrm{~m}^{3} / \mathrm{hr}$, respectively, as shown in Fig. 5 . Overall the trickling filter system removed TSS up to $39 \mathrm{mg} / \mathrm{l}$ with removal efficiency of $38-56 \%$. Variation in treatment efficiency was recorded due to the accumulation of slough-off material or degradation of solids from filter media during the operation of the trickling filter system [25].

TDS is also an important parameter in WW treatment, which indicates the physical state of principal constituents. During the study, influent TDS values ranged from 560 to $720 \mathrm{mg} / \mathrm{l}$ and effluent was 380 to $530 \mathrm{mg} / \mathrm{l}$. The trickling filter system reduced TDS value up to $380 \mathrm{mg} / \mathrm{l}$. The trickling filter system showed average removal efficiency of $28,29,32$, and $25 \%$ at flow rates of $2.6,3.8,1.7$, and $4.6 \mathrm{~m}^{3} / \mathrm{hr}$, respectively (Fig. 6). The decrease in efficiencies of TSS and TDS with increasing flow rate may be due to the higher hydraulic loading rate, which may reduce the residence time of WW in a trickling filter, which reduces the contact between liquid and biofilm [36]. During the operation of the trickling filter system the removal efficiency of TDS was in the range of 20 to $35 \%$. The decrease in TDS value was recorded due to the conversion $\mathrm{NO}_{3}$ to $\mathrm{N}_{2}$ (diatomic Nitrogen), and also was responsible for electrical conductivity (EC) in WW. Many of the other

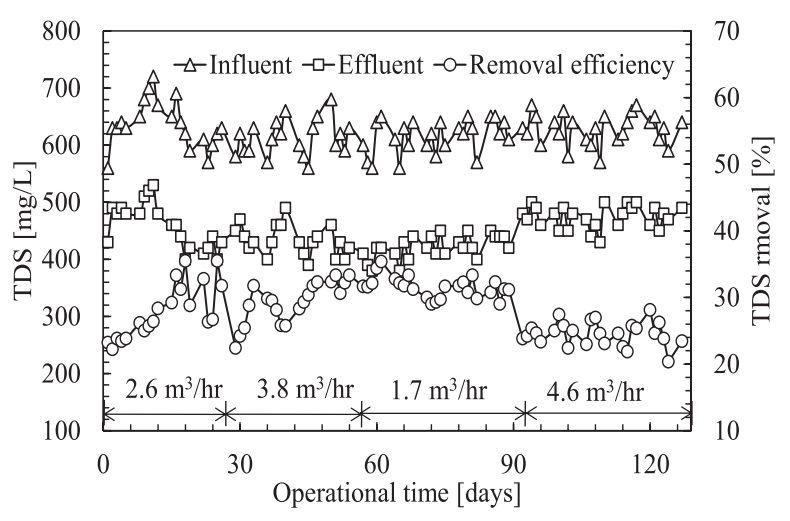

Fig. 6. TDS removal efficiency profile observed for trickling filter system. 


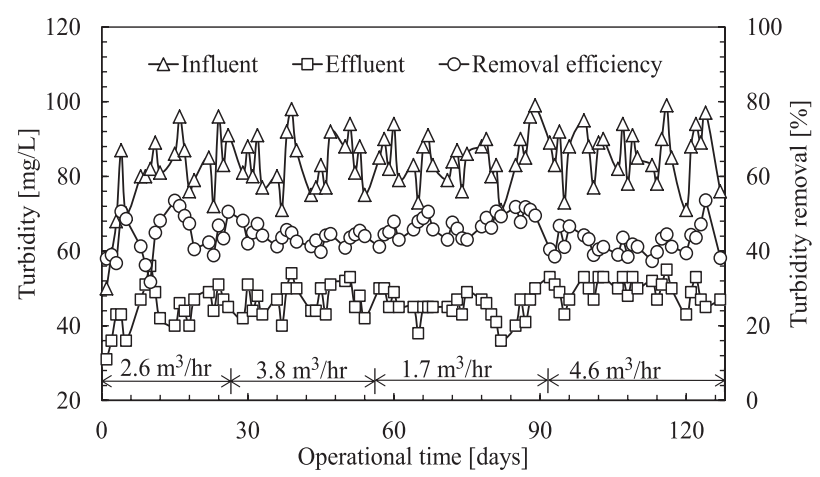

Fig. 7. Turbidity removal efficiency profile observed for trickling filter system.

studies concluded that dissolved solids, suspended solids, and COD are related to electrical conductivity levels in WW. The higher value of solids shows more EC [25, 4852].

\section{Turbidity and Color}

Turbidity is another important parameter in WW treatment, which indicates the growth of pathogens responsible for waterborne diseases [53-54]. Turbidity in WW may be due to presence of particulate and organic dissolved matters. The TF system was operated at four different flow rates and tested for removal of turbidity. Influent values of turbidity ranged from 50 to 99 FAU, and after the treatment effluent values ranged from 31 to 56 FAU as shown in Fig. 7. Average removal efficiency received $44,44,47$, and $42 \%$ at flow rates of 2.6, 3.8, 1.7, and $4.6 \mathrm{~m}^{3} / \mathrm{hr}$, respectively. During the operation of the trickling filter system, overall removal efficiency ranged from 32 to $57 \%$. This decrease in turbidity was recorded due to degradation of organic compounds present in WW by microorganisms attached to the filter media $[25,50$, 53, 55-56]. During the study we also investigated how turbidity removal is related to $\mathrm{COD}$ reduction. As turbidity in WW decreases, the COD value also is reduced and vice versa $[25,51]$.

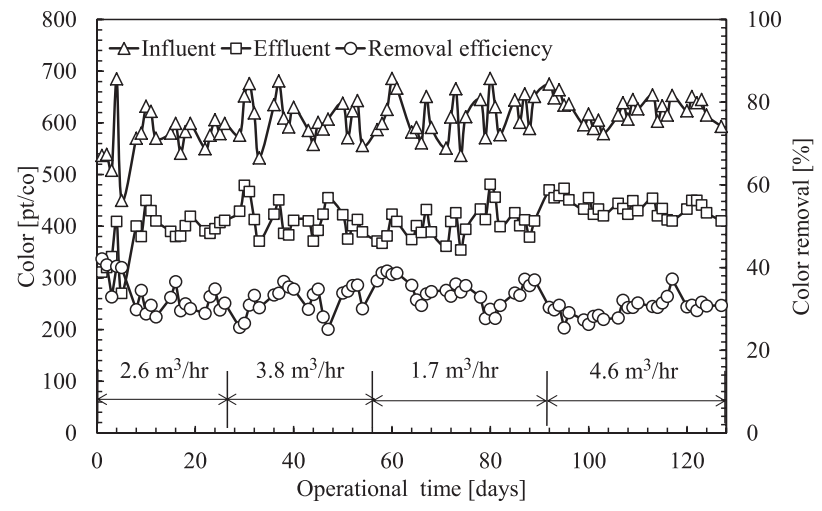

Fig. 8. Color removal efficiency profile observed for trickling filter system.
Color removal is another important parameter in WW treatment because it contains visible contaminants. It is necessary to remove color from WW due to its toxicity, but also due to aesthetic impacts on receiving bodies. The trickling filter system was operated at four different flow rates for color removal. Concentration of color in influent ranged from 450 to $686 \mathrm{pt} / \mathrm{co}$ and after the treatment its concentration ranged from 270 to $481 \mathrm{pt} / \mathrm{co}$. Average color removal efficiency was $33,32,34$, and $30 \%$ at flow rates of $2.6,3.8,1.7$, and $4.6 \mathrm{~m}^{3} / \mathrm{hr}$, respectively, as shown in Fig. 8. During the operation of the trickling filter system maximum color removal efficiency was up to $42 \%$. Color removal in WW was due to reduction in dissolved solids, suspended solids, and turbidity. Many researchers explained that color in WW occurs due to the presence of dissolved minerals, organics, and chemicals. Reduction in color occurred due to adsorption capability of filter media $[25,33,48]$.

\section{Conclusions}

In the present study, the TF system using cotton sticks as support material was successfully tested for municipal WW treatment for under-developed and/or developing countries, particularly for Asia and Africa. The TF system using cotton sticks as filter media proved that municipal WW can be handled in an environmentally friendly and cost-effective manner. During the study results confirmed that the TF system successfully removed contaminants (including BOD, COD, TSS, TDS, turbidity, and color) which lies under PEPA NEQS for re-use in agriculture. The TF system was tested at different flow rates of 1.7, $2.6,3.8$, and $4.6 \mathrm{~m}^{3} / \mathrm{hr}$. At a low flow rate $1.7 \mathrm{~m}^{3} / \mathrm{hr}$ the TF system using cotton sticks as support media showed about $78 \%$ of BOD and $80 \%$ COD removal efficiency. By increasing the flow rate about 2.70 times, the system efficiency was up to $70 \%$. Additionally, the TF system using cotton sticks as support media removed TSS 38 to $56 \%$, TDS 20 to $36 \%$, turbidity 31 to $56 \%$, and color up to $42 \%$.

\section{Acknowledgements}

The authors acknowledge financial support from the Higher Education Commission (HEC) of Pakistan under the research project titled: "Development and adoption of waste water treatment technologies for safe Re-use of Municipal wastewater and associated Bio-solids in Multan region", Project No. 20-2894/NRPU/R\&D/HEC/1376.

\section{References}

1. SATO T., QADIR M., YAMAMOTO S., ENDO T., ZAHOOR A. Global, regional, and country level need for data on wastewater generation, treatment, and use. Agricultural Water Management. 130, 1, 2013. 
2. QADIR M., SHARMA B.R., BRUGGEMAN A., CHOUKR A.R., KARAJEH F. Nonconventional water resources and opportunities for water augmentation to achieve food security in water scarce countries. Agricultural Water Management. 87, 2, 2007.

3. MUTHUKRISHNA V.K., VICTOR N.D. Study on recycling urban wastewater for non-potable uses for water conservation. Pol. J. Environ. Stud. 25 (1), 167, 2016. DOI: $10.15244 /$ pjoes $/ 59273$

4. JING L., YUBAO W., ZHONGBO Y., XINCHUN C., LEI T., SHIKUN S., PUTE W. A comprehensive analysis of blue water scarcity from the production, consumption, and water transfer perspectives. Ecological Indicators 72, 870, 2017.

5. NABEELA F., AZIZULLAH A., BIBI R., UZMA S., MURAD W., SHAKIR S.K., ULLAH W., QASIM M., HADER D.P. Microbial contamination of drinking water in Pakistan - a review. Environ Sci. Pollut. Res. Int. 21 (24), 13929, 2014.

6. MEKONNEN M.M., HOEKSTRA A.Y. Four billion people facing severe water scarcity. Sci. Adv. 2 (2), 2016. DOI: 10.1126/sciadv. 1500323

7. PEDRO-MONZONÍS M., SOLERA A., FERRER J., ESTRELA T., PAREDES-ARQUIOLA, J. A review of water scarcity and drought indexes in water resources planning and management. J. Hydrol. 527, 482, 2015.

8. FLORKE M., KYNAST E., BARLUND I., EISNER S., WIMMER F., ALCAMO J. Domestic and industrial water uses of the past 60 years as a mirror of socio-economic development: a global simulation study Glob. Environ. Change, 23, 144, 2013.

9. MURTAZA G., GHAFOOR A., QADIR M. Disposal and use of sewage on agricultural lands in Pakistan-a review, Pedosphere. 20 (1), 23-34. 2010.

10. PWSS. Pakistan Water Sector Strategy National water sector profile, Ministry of Water and Power, Office of the Chief Engineering Advisor 5, 2002. Available at http://waterinfo. net.pk/cms/pdf/vol5.pdf 122

11. WB-CWRAS Pakistan country water resources assistance strategy water economy: Running dry', 34081-PK, Agriculture and Rural Development Unit, World Bank, 2005, 121, 2005.

12. ENSINK J.H.J., MAHMOOD T., VAN D.H.W., RASCHID S.L., AMERASINGHE F.P. A nationwide assessment of wastewater use in Pakistan: an obscure activity or a vitally important one? Water Policy. 6, 197, 2004.

13. KUMAR B.R., PERSAD M.L., RAO D.S., RAO K.R. S.S. Bioremediation of Sewage using Specific Microbial consortium and Biogenic Filter materials. Indian Journal of Research 2 (11), 1, 2013.

14. MARYAM K.G., ROSNAH B.M.Y. Advantages and disadvantages of healthcare waste treatment and disposal alternatives: Malaysian Scenario (Review) Pol. J. Environ. Stud. 25 (1), 17-2, 2016. DOI: 10.15244/pjoes/59322

15. MAYOWA O.A., CAROLINA H.P., ANOFI O.T.A. A Review of the application of biofloccualnts in wastewater treatment Pol. J. Environ. Stud. 25 (4), 1381, 2016. DOI: $10.15244 /$ pjoes/61063

16. MONIKA S., TOMAS V., JAN M., TOMAS L. Microbial contamination of screenings from wastewater treatment plants. Pol. J. Environ. Stud. 21 (6), 1943, 2012.

17. ENSINK J.H.J., VAN D.H.W., AMERASINGHE F.P. Giardia duodenalis infection and wastewater irrigation in Pakistan. Transactions of the Royal Society of Tropical Medicine and Hygiene. 100 (6), 538, 2006.

18. MARIA K., BEATE I.E., PETA A.N., MARTIN K., KLARA H., JIRÍ N., IVANA T., TOBIAS S., SVEN S.,
MUHAMMAD A.K.H., JORG A., WERNER B. Impact of untreated wastewater on a major European river evaluated with a combination of in vitro bioassays and chemical analysis. Environmental Pollution 220, 1220, 2017.

19. AZIZULLAH A., KHATTAK M.N.K., RICHTER P., HAIDER D.P. Water pollution in Pakistan and its impact on public health-A review. J. Environ. Intl. 37, 479, 2011.

20. SHAH M., HASHMI H.N. Macrophyte waste stabilization ponds: An option for municipal WW treatment. International Journal of Physical Sciences.7 (30), 5162, 2012.

21. PATEL D.K., KANUNGO V.K. Comparative ecophysiological potential of a submerged and a free floating aquatic plant to treat domestic wastewater. Journal of Ecobiotechnology. 4 (1), 61, 2012.

22. GUO J., PENG Y.Z., GUO J.H., MA J., WANG W., WANG B. G. Dissolved organic matter in biologically treated sewage effluent (BTSE): Characteristics and comparison. Journal of Desalination. 278 (1-3), 365, 2011.

23. QINGLIANG Z., HUIYUAN Z., KUN W., LIANGLIANG W., JINLI L., YU L. Removal and transformation of organic matters in domestic wastewater during lab-scale chemically enhanced primary treatment and a trickling filter treatment. Journal of Environmental Sciences. 25 (1), 59, 2013.

24. CHAN C.C.V., NEUFELD K., CUSWORTH D., GAVRILOVIC S., NGAI T. Investigation of the effect of grain size, flow rate and diffuser design on the CAWST biosand filter performance. Int. J. Serv. Learn. Eng. Humanit. Eng. Soc. Entrep. 10 (1), 1, 2015.

25. IMRAN A., ZAHID M.K., MUHAMMAD S., MUHAMMAD H.M., HAFIZ U.F., MOHSIN A., ABDUL N. Experimental study on Maize Cob trickling filter-based wastewater treatment system: design, development, and performance evaluation. Pol. J. Environ. Stud. 25 (6), 2265, 2016. DOI: $10.15244 /$ pjoes $/ 63657$

26. RAJA S., CHEEMA H M.N., BABAR S., KHAN A.A., MURTAZA G., ASLAM U. Socio-economic background of wastewater irrigation and bioaccumulation of heavy metals in crops and vegetables. Agri. Water Manag. 158, 26, 2015.

27. METCALF., EDDY H. Wastewater Engineering: Treatment, Disposal, and Reuse. $4^{\text {th }}$ ed. The McGraw-Hill Companies. New York, New York 887-981, 2003.

28. EDING E.H., KAMSTRAB A., VERRETH J.A.J. Design and operation of nitrifying trickling filters in recirculating aquaculture: A review. Aqua. Eng. 34 (3), 234, 2006.

29. HAIMANOT H.L., HARTMUT E. A pilot scale trickling filter with pebble gravel as media and its performance to remove chemical oxygen demand from synthetic brewery wastewater. Biomedicine \& Biotechnology (Journal of Zhejiang University-SCIENCE B), 14 (10), 924, 2013.

30. APHA. Standard Methods for the Examination of Water and Wastewater. $22^{\text {nd }}$ edition, APHA-AWWA-WEF, Washington, D.C. 2012: 85, 106, 2012.

31. GARCIA M.J.J., POYATOS J.M., HONTORIA E. The influence of biofilm treatment systems on particle size distribution in three wastewater treatment plants. Wat. Air Soil Pollut. 212 (1/4), 37, 2010.

32. HEALY M.G., RODGERS M., BURKE P. Quantification of biofilm build-up in filters when intermittently loaded with low-strength synthetic wastewater, Desalination, 271, 105, 2011.

33. KORNAROS M., LYBERATOS G. Biological treatment of wastewaters from a dye manufacturing company using a trickling filter. Journal of Hazardous Materials.136, 95, 2006. 
34. PAK EPA. Pakistan Environmental Legislation and the NEQS. Pakistan Environmental Protection Agency. October, 1997.

35. WEI L., CHUNPING Y., HUIJUN H., GUANGMING Z., SEN Y., YAN C. Novel two-stage vertical flow biofilter system for efficient treatment of decentralized domestic wastewater Ecological Engineering 64, 415, 2014.

36. RAJ S.A., MURTHY D.V.S. Synthetic dairy wastewater treatment using cross flow medium trickling filter. Journal of Environmental Science and Health, Part A: Toxic/Hazardous Substances and Environmental Engineering. 357, 2008. http://dx.doi.org/10.1080/109345299093768411

37. HONGLEI W., GUODONG J., XUEYUAN B., CHUNGUANG $\mathrm{H}$. Assessing nitrogen transformation processes in a trickling filter under hydraulic loading rate constraints using nitrogen functional gene abundances. Bioresource Technology 177, 217, 2015.

38. CHANDAN M., GUPTA S. K. Hybrid Reactor for Priority Pollutant Trichloroethylene Removal. Water Research. 35 (1), 160, 2001.

39. OPARA C.C., ADEDEJI A.A., ONUABUCHI A. Biological treatment of platform wastewater using bench-scale trickling filters. Greener Journal of Biological Sciences. 3 (2), 084, 2013.

40. RAJ S.A., MURTHY D.V.S. Comparison of the trickling filter models for the treatment of synthetic dairy wastewater, Bioprocess Eng. 21 (1), 51, 1999. DOI: 10.1080 $/ 10934529909376841$

41. TAKEYUKI S., SIRIWAT J., TOSHIHIRO H., MARC A., DESHUSSES. Removal of ammonia from contaminated air in a biotrickling filter-Denitrifying bioreactor combination system. Water research. 42, 4507, 2008.

42. MAHMOOD A. Development of biofilm on geotextile in a new multi-zone wastewater treatment system for simultaneous removal of COD, nitrogen and phosphorus. Bioresource Technology. 107, 78, 2012.

43. MARCIN Z. Application of microwave radiation to biofilm heating during wastewater treatment in trickling filters. Bioresource Technology. 127, 223, 2013.

44. SAIMA F., BEIPING Z., QAISAR M. Biological treatment of combined industrial wastewater. Ecological Engineering 84, 551, 2015.

45. MAENG M.S., PARK J.G., LEE H.G., JOHN E.T., DOCKKO S. Sustainable technology of trickling biosand filter (TBSF) combined with rock media to reduce organic matters for drinking water. Desalin. Water Treat. 57 (17), 1, 2015. http://dx.doi.org/10.1080/19443994.2015.1062427

46. WANG J., SHI H., QIAN Y. Wastewater treatment in a hybrid biological reactor (HBR): effect of organic loading rates. Process Biochem. 36, 297, 2000.

47. WIJEYEKOON S., MINOT., SATOH H., MATSUO T. Effects of substrate loading rate on biofilm structure. Water Research. 38, 2479, 2004.

48. DOAN H.D., WU J., EYVAZI M.J. Effect of liquid distribution on the organic removal in a trickle bed filter Chemical Engineering Journal 139, 495, 2008.

49. KIM B., GAUTIER M., PROST B., MOLLE P., MICHEL P., GOURDON R. Performance evaluation of partially saturated vertical- flow constructed wetland with trickling filter and chemical precipitation for domestic and winery wastewaters treatment. Ecological Engg. 71, 41, 2014.

50. PITCHARD M., MKANDAWIRE T., NEILL J.G.O. Biological, chemical and physical drinking water quality from shallow wells on Malawi: Case study of Blantyre, Chiradzulu and Mulanje. Phy Chem Earth. 32, 1167, 2007.

51. ABDUL R., IFFAT N., ZIA U.K., RAFIQ M., NAEEM A., SAFIA A. Sequential application of plastic media-trickling filter and sand filter for domestic wastewater treatment at low temperature condition. British Biotechnology Journal. 2 (4), 179, 2012.

52. MARCOS R.V. Wastewater treatment in trickling filters using Luffa Cyllindrica as biofilm supporting medium. Journal of Urban and Environmental Engineering. 6 (2), 57, 2012.

53. MAENG M.S., CHOI E.S., DOCKKO S. Reduction of organic matter in Drinking water using a hybrid system combined with a rock biofilter and membrane in developing countries. Int. Biodeterior.Biodegrad.102, 223, 2015.

54. CHAVEZ A., JIMENEZ B., MAYA C. Particle size distribution as useful tool for microbial detection. Wat Sci Technol. 50, 179, 2004.

55. GARCIA J.J., POYATOS J.M., HONTORIA E. The Influence of biofilm treatment systems on particle size distribution in three wastewater treatment plants. Wat Air Soil Pollution. 212, 37, 2010.

56. GWY A.S., TAE Y.K., HO S.K., MIN S.M., SEOK D. Membrane hybrid system combined with a trickling filter and a thin layer of biosand to reduce high levels of organic matter in drinking water in developing countries. Process Safety and Environmental Protection 104, 541, 2016. 